\title{
UPAYA KEPALA SEKOLAH DAN GURU PENDIDIKAN AGAMA ISLAM DALAM MENCEGAH PENYALAHGUNAAN NARKOBA DI SMA PAB 4 SAMPALI DELI SERDANG
}

\author{
Ahmad Khoir \\ Guru SMA PAB 4 Sampali Deli Serdang
}

\begin{abstract}
Abstrak
Islam menempatkan manusia dimuka bumi inisebagai khalifah. Kata khalifah, setidaknya bermakna, pertama pengganti, yakni pengganti Allah SWT untuk melaksanakan titah-Nya di muka bumi, dan kedua pemimpin yang kepadanya diserahi tugas untuk memimpin diri sendiri, makhluk lainnya, memakmurkan dan mendayagunakan alam untuk kepentingan manusia secara keseluruhan. Dengan kata lain, wajib bagi kita menjauhi segala bentuk kejahatan terkhusus saat ini merebahnya penyalahgunaan narkoba.
\end{abstract}

\section{Kata Kunci; Guru, Narkoba}

\section{PENDAHULUAN}

Dunia pendidikan saat ini, tengah dilanda bencana besar, maka segenap kekuatan harus dikerahkan untuk mengantisipasi bencana itu, supaya jangan menjangkit lebih luas lagi ke berbagai penjuru nusantara. Bencana besar itu adalah " Narkoba ". Penyalahgunaan narkoba saat ini dikalangan generasi muda khususnya pelajar sungguh memprihatinkan. Narkoba telah merengkut kesehatan mereka, narkoba telah menghancurkan masa depan mereka, narkoba membuat mereka tidak waras, narkoba membuat mereka berbuat kriminalitas, narkoba membuat mereka kehilangan segalanya, bahkan nyawa menjadi taruhannya.

Penyalahgunaan narkoba penyebab rusaknya moral generasi muda khususnya pelajar, padahal tujuan diselenggarakannya pendidikan begitu sangat mulia. Sebagaimana yang diamanatkan dalam UU RI no 20 Tahun 2003 tentang Sistem Pendidikan Nasional, bahwa: Pendidikan Nasional berfungsi mengembangkan kemampuan dan membentuk watak serta peradaban bangsa yang bermartabat dalam rangka mencerdaskan kehidupan bangsa, bertujuan untuk mengembangkan potensi peserta didik menjadi manusia yang beriman dan bertakwa kepada Tuhan Yang Maha Esa serta berakhlak mulia (UU No 2 tahun 2003).

Untuk mencapai tujuan di atas maka Pendidikan Agama Islam merupakan upaya membina dan mengembangkan potensi manusia agar dapat menjalankan ajaran-ajaran Islam secara kaffah. Dalam hal ini Allah 
SWT menegaskan dalam firman-Nya:"Hai orang-orang yang beriman,masuklah kamu ke dalam Islam keseluruhan dan janganlah kamu turut langkah-langkah syaitan. Sesungguhnya syaitan itu musuh yang nyata bagimu." ( Q.S. Albaqarah: 02: 208 ).

Di dalam tafsir Shafwatut tafasir karangan syaikh Muhammad Ali Ash-shabuni hal 269 menerangkan bahwa " hai orang-orang yang beriman, masuklah kamu ke dalam islam keseluruhan". Maksudnya adalah masuklah kamu ke dalam Islam secara keseluruhannya, melaksanakan semua hukum-hukum dan syariat-syariatnya, dan janganlah kamu mengambil sebagian hukum dan meninggalkan sebagian hukum lainnya. Maksudnya, janganlah kamu melaksanakan shalat dan meninggalkan zakat, Islam adalah keseluruhan tidak terpisah-pisahkan. "Dan janganlah kamu turut langkah-langkah setan. Sesungguhnya setan itu musuh yang nyata bagimu". Maksudnya janganlah kamu mengikuti jalan setan dan keinginannya, sesungguhnya setan adalah musuh nyata bagimu.

Dalam berbangsa dan bernegara, bangsa ini memiliki pemerintahan yang kuat dan bersahaja, salah satu upaya pemerintah dalam mencerdaskan kehidupan bangsa adalah memperbaiki Sistem Pendidikan Nasional. Maka dengan dasar komitmen itu, Perhatian pemerintah terhadap dunia pendidikan sangat tinggi, terbukti bahwa pemerintah melalui UU menerangkan 20\%( persen ), anggaran APBD/APBN dikhususkan untuk pendidikan, sebagaimana yang tertuang di UUD 1945 pasal 31 ayat 4 dan UU Sistem Pendidikan Nasional nomor 20 tahun 2003 pasal 49 ayat 1 (UU Sisdiknas, 2003).

Pendidikan Nasional bertujuan untuk membentuk manusia seutuhnya, bermoral, berakhlak mulia, cerdas, cinta terhadap tanah air, tanpa mengotori, menodai nilai-nilai pancasilais dan norma-norma Agama Islam. Sebagai generasi penerus bangsa, kita mempunyai tanggung jawab yang besar, dalam memajukan bangsa ini di kancah Internasional, salah satunya melalui dunia pendidikan.

Pendidikan Nasional akan mengalami kemajuan, berkualitas terbaik, cerdas dan bermartabat tinggi, religius, tentunya tidak terlepas dari pengaruh, sumbangsih dari para pendidik. Guru sangat berperan aktif dalam membentuk kualitas manusia yang baik, cerdas dan berilmu pengetahuan serta modern. Guru satu komponen terpenting dalam mencerdaskan kehidupan bangsa yang berakhlak dan bermoral pancasilais.

Lebih lanjut lagi, bahwa pendidikan yang pertama didapatkan seorang anak tentunya di lingkungan keluarga. Dalam keluargalah 
pertama kali anak mendapat sentuhan pendidikan dari kedua orang tuanya, terutama ibu. Secara literal keluarga merupakan unit sosial terkecil yang terdiri dari orang yang berada dalam seisi rumah yang sekurang-kurangnya terdiri dari suami istri. KBBI (1991:471).

Keluarga merupakan masyarakat alamiah yang pergaulan diantara anggotanya bersifat khas. Dalam lingkungan ini terletak dasar-dasar pendidikan. Disini pendidikan berlangsung dengan sendirinya sesuai dengan tatanan pergaulan yang berlaku di dalamnya, artinya tanpa harus diumumkan atau dituliskan terlebih dahulu agar diketahui dan diikuti oleh seluruh keluarga. Disini diletakkan dasar-dasar pengalaman melalui rasa kasih sayang dan penuh kecintaan, kebutuhan akan kewibawaan dan nilai-nilai kepatuhan. Justru karena pergaulan yang demikian itu berlangsung dalam hubungan yang bersifat pribadi dan wajar, maka penghayatan terhadapnya mempunyai arti yang amat penting. Daradjat, (1996: 66)

Mengenai lingkungan sekolah dan masyarakat yang merupakan sendi-sendi pendidikan yang fundamental, maka keluarga lebih kuat dari pada semua sendi-sendi itu. Sebab sejak awal masa kehidupannya, anak menerima pengaruh dari keluarga dan waktu yang dihabiskannya di lingkungan keluarga lebih banyak dari pada tempat-tempat lain. Disamping itu kedudukan orang tua lebih banyak berpengaruh terhadap anak. Muhammad Quthb (1401 H). Dengan demikian, peran keluarga sangat penting dalam membentuk kepribadian anak yang berkarakter baik. Sebab keluarga yang terdiri dari ibu dan ayah sebagai dalang percontohan anak-anaknya di rumah.

Semestinya menjadi seorang guru, jadilah guru yang profesional, mengabdi dengan ikhlas, memberikan penampilan terbaik, membentuk akhlak terpuji, seperti yang disampaikan oleh zakiah daradjat. Lebih lanjut, guru profesional itu akan tercermin dalam pelaksanaan pengabdian tugas-tugas yang ditandai dengan keahlian baik dalam materi maupun metode. Selain itu juga, ditunjukkan melalui tanggung jawabnya dalam melaksanakan seluruh pengabdiannya. Guru yang professional hendaknya mampu memikul dan melaksanakan tanggung jawab sebagai guru kepada peserta didik, orang tua, masyarakat, tanggung jawab, bangsa, Negara, dan agamanya. Guru profesinal mempunyai tanggung jawab pribadi, yang mandiri yang mampu memahami dirinya, mengelola dirinya, mengendalikan dirinya, dan menghargai serta mengembangkan dirinya. Kunandar, (2007:47) 
Kepala sekolah, guru dan siswa satu kesatuan yang tidak dapat terpisahkan. Kepala sekolah yang memahami tugas dan fungsinya dengan baik, dan terlaksana pula dengan baik, akan menghasilkan sekolah yang bermartabat. Demikian pula dengan guru, mengerti akan tugas dan tanggung jawabnya. Maka apabila kepala sekolah dan guru telah sepakat untuk meningkatkan kinerjanya dan mengabdi dengan ikhlas. Tentulah hasilnya akan luar biasa, mencetak siswa/I yang berakhlak terpuji dan berilmu pengetahuan.

Namun perlu untuk diketahui bahwa pada abad ke-21 pendidikan kita telah mengalami pergeseran perubahan paradigma. Menurut Kunandar (2007:13) “yang meliputi pergeseran paradigma adalah sebagai berikut : (1) dari belajar terminal ke belajar sepanjang hayat (2) dari belajar berfokus penguasaan pengetahuan ke belajar holistic, (3) dari citra hubungan guru-murid yang bersifat konfrontatif ke citra hubungan kemitraan, (4) dari pengajar yang menekannkan pengetahuan skolastik (akademik) ke penekanan keseimbangan focus pendidikan nilai, (5) dari kampanye melawan buta aksara ke kampanye melawan buat teknologi, budaya dan computer, (6) dari penampilan guru terisoli ke penampilan dalam tiga tim kerja, (7) dari konsentrasi eksklusif pada kompetisi ke orientasi kerja sama.Dengan demikian pendidikan kita dihadapkan pada tantangan untuk menghasilkan sumber daya manusia yang berkualitas dalam menghadapi berbagai tantangan dan tuntutan zaman yang bersifat kompetitif.

Penyalahgunaan narkoba, sedang menjangkit dihati masyarakat, tidak menutup kemungkinan narkoba telah menyebar di pemerintahan, di lingkungan sekolah, kalangan artis, kalangan para pejabat, rakyat jelata, elit politik, intelektual, bahkan pelajar sekalipun sudah menjadi sasaran utama bagi yang namanya narkoba.Pemerintah dengan segala upayanya, telah mendeklarasikan bahwa wajib bagi seluruh rakyat Indonesia untuk memerangi narkoba. Sebab generasi muda Indonesia dewasa ini, sedang diracGenerasi muda yang termasuk sebagai makluk sosial yang tidak dapat hidup sendiri dan juga memerlukan bantuan orang lain, pasti akan menjalin kerjasama dengan orang lain atau lingkungan di luar dirinya, misalnya lingkungan keluarga, yakni orang tua, saudara, kerabat serumah atau yang jauh, dan juga lingkungan masyarakat disekitarnya.

b). Lingkungan Sekolah

Sekolah merupakan salah satu lembaga pendidikan formal yang telah dimodifikasi sedemikian rupa untuk mengantarkan anak didiknya sesuai dengan tujuan yang diinginkan, sekolah merupakan lembaga 
dalam membina generasi muda dalam menghadapi masa depannya, dan hendaknya sekolah dapat memberikan dorongan kepada generasi muda agar mampu berkembang semaksimal mungkin sesuai dengan bidangnya masing-masing sehingga dapat berguna bagi bangsa dan Negara. Fatimah, ( $2006: 176$ )

Sekolah sebagai sarana pendidikan bagi anak yang paling tepat, karena tidak semua tugas orang tua dalam mendidik serta membina anak dapat dilakukan sepenuhnya oleh masing-masing orang tua dari sang anak, maka dari itu sekolah sebagai lembaga formal yang berfungsi sebagai membina dan mendidik anak dapat berfungsi membantu para orang tua dalam mendidik serta membina anak-anak mereka, di samping itu juga sekolah juga dapat sebagai sarana atau jembatan bagi anak untuk berinteraksi dengan kehidupan masyarakat

c). Lingkungan Masyarakat

Masyarakat merupakan bagian dari suatu Negara, dan generasi muda termasuk bagian dari masyarakat, dari lingkungan masyarakat inilah biasanya terjadi permasalahan yang lebih kompleks dari sekolah atau keluarga, mau atau tidak mau generasi muda harus masuk dalam lingkungan masyarakat, otomatis harus mengikuti aturan dan norma yang ada di masyarakat tersebut. Dan begitu pula generasi muda dituntut untuk ikut serta dalam membangun lingkungan masyarakat.

Dalam lingkungan masyarakat sangat menentukan dalam upaya pembentukan watak dan karakter dari generasi muda tersebut, lingkungan yang sehat dan mendukung generasi muda tersebut turut menjadi sehat, begitu juga sebaliknya, dalam menunjukkan jati dirinya ditengah masyarakat tidak boleh diremehkan perannya sekalipun oleh orang tua, dalam masyarakat itu sendiri semua pihak harus turut serta berpartisipasi dalam membangun lingkungan.Fatimah, ( $2006: 175$ ).

\section{KAJIAN TEORETIS}

\section{Penyalahgunaan Narkoba}

Narkotika atau obat bius yang bahasa Inggrisnya disebut "narcotic" adalah semua bahan obat yang mempunyai efek kerja pada umumnya bersifat :

a) Membius menurunkan kesadaran

b) Merangsang meningkatkan semangat kegiatan / aktivitas

c) Ketagihan ketergantungan, mengikat, dependence.

d) Menimbulkan daya berkhayal ( halusinasi).Sudiro (2000:13) 
Narkotika berdasarkan ketentuan umum Pasal 1 Angka 1 UndangundangNarkotika, bahwa yang dimaksud dengan Narkotika adalah zat atau obat yang berasal dari tanaman atau bukan tanaman, baik sintesis maupun semisintesis, yang dapat menyebabkan penurunan atau perubahan kesadaran, hilangnya rasa, mengurangi sampai menghilangakan rasa nyeri, dan dapat menimbulkan ketergantungan. ( UU RI, Narkotika : 2011 ).

Sekilas wajib bagi kita mengetahui sanksi hukum bagi pembuat dan pengedar narkoba begitu di perhatikan oleh pemerintah. Peredaran narkoba dalam hukum positif di Indonesia diatur di dalam Undangundang No. 22 Tahun 1997 tentang narkotika. Menurut Undang-undang No. 22 Tahun 1997 tentang Narkotika, peredaran gelap narkotika adalah " setiap kegiatan atau serangkaian yang dilakukan secara tanpa hak dan melawan hukum yang ditetapkan sebagai tindak pidana narkotika “. ( UU RI, Narkotika : 2011 ).

Adapun sanksi hukuman yang diberikan bagi para pengedar narkotika dengan pidana minimal penjara 2 tahun dan pidana maksimal hukuman mati atau seumur hidup yang diatur dalam BAB XII yaitu pasal 78, 79, 80, 82, 83, 84, 87 dan pasal 96, 97, 98, 99, dan pasal 100, Undangundang No. 22 Tahun 1997 tentang Narkotika.

\section{Narkoba dalam Perspektif Islam}

Dalam pandangan Islam, Narkoba sesuatu yang membahayakan apabila salah menggunakannya. Penyalahgunaan narkoba dapat merusak perkembangan jiwa generasi muda baik bagi si pengguna maupun orang lain. Dalil yang menunujukkan keharaman narkoba secara qoth'i telah disinyalir didalam Alqur'an sebagai berikut

Artinya. Hai orang-orang yang beriman, sesungguhnya (meminum) khamar, berjudi, (berkorban untuk) berhala, mengundi nasib dengan panah, adalah termasuk perbuatan syaitan. Maka jauhilah perbuatan-perbuatan itu agar kamu mendapat keberuntungan. ( Q.S.Al maidah : 90 )

Sementara itu, menurut Dr. Yusuf Al-Qardhawi bahwa ganja, heroin, serta bentuk lainnya baik padat maupun cair yang terkenal dengan sebutan Mukhaddirat (narkotik) adalah termasuk benda-benda yang diharamkan syara' tanpa diperselisihkan lagi di antara ulama. Qardhawi ( 1995:792)

Menurut pandangan Islam, setiap perbuatan yang membahayakan fisik maupun mental manusia adalah terlarang. Hukum penyalahgunaan narkoba jelas haram dan mendapat sanksi yang berat. Dalam Islam ada 
kaedah sadduz zari'ah yang berarti menutup pintu kepada perbuatan jahat. Wahid, (2014:179-180).

Dalam pandangan Islam, penetapan haramnya narkoba diambil dari Qiyas. Qiyas adalah mempersamakan / menganalogikan masalah baru yang tidak terdapat dalam alquran ataupun hadis. Narkoba disamakan dengan khamar, keharaman khamar sudah jelas di dalam alquran.

Dalam Hal Ini, Ulama sepakat tentang keharaman mengkonsumsi dan membuat narkoba ketika tidak dalam keadaan darurat, Para ulama menetapkan keharamannya berdasarkan sejumlah firman Allah SWT. Sebagai berikut:Dan menghalalkan bagi mereka segala yang baik dan mengharamkan bagi mereka. ( Q.S. Al- A'raaf: 157 ).

Islam Memiliki fungsi mengatur kehidupan manusia. Mewujudkan kemaslahatan yang hakiki, Menolak segala bentuk mafsadah ( kerusakan ) dan kejahatan, sesuai bukti empirik dari berbagai penelitian hukumhukum ibadah. Serta hubungan sosial bermasyarakat yang diajarkan oleh Isldam. Penyalahgunaan narkoba sangat berbahaya ( mafsadah ) merusak setiap diri yang salah menggunakannya.

Keterangan-keterangan diatas menguatkan bahwa penyalahgunaan narkoba dalam pandangan Islam adalah haram, karena dapat merusak akal, ketergantungan dan penyebab kematian.

\section{Narkoba dalam Perspektif Undang-undang}

Dalam undang-undang narkotika dan psikotropika nomor 35 tahun 2009 pasal 1 menerangkan bahwa : Narkotika adalah zat atau obat yang berasal dari tanaman atau bukan tanaman, baik sintesis maupun semisintesis, yang dapat menyebabkan penurunan atau perubahan kesadaran, hilangnya rasa, mengurangi sampai menghilangkan rasa nyeri dan dapat menimbulkan ketergantungan, yang dibedakan ke dalam golongan-golongan sebagaimana yang terlampir dalam undang-undang ini. Dari keterangan diatas jelas bahwa narkoba sangat berbahaya apabila disalahgunakan.

Berikut ini, penulis akan memaparkan beberapa hal mengenai narkoba diantaranya:

1). Pendapat Tokoh Tentang Narkoba

Menurut Dadang Hawari dalam penelitiannya membuktikan bahwa penyalahgunaan narkoba dapat menimbulkan beberapa dampak antara lain, merusak hubungan kekeluargaan, menurunkan kemampuan belajar, ketidakmampuan untuk membedakan mana yang baik dan mana yang 
buruk, perubahan perilaku menjadi anti-sosial, merosotnya produktivitas kerja, gangguan kesehatan, mempertinggi kecelakaan lalu lintas, kriminaliatas dan tindak kekerasan lainnya baik kuantitatif maupaun kualitatif. Hawari, (1999:133).

Selanjutnya Dadang Hawari menjelaskan permasalahan narkoba ini mempunyai dimensi yang luas dan kompleks, baik dari sudut medis, psikiatrik, kesehatan jiwa, maupun psikososial (ekonomi, politik, sosialbudaya, kriminalitas dan lain sebagainya). Penyalahgunaan narkoba adalah penyakit endemik dalam masyarakat modern, merupakan penyakit kronik yang berulang kali kambuh, yang hingga sekarang belum ditemukan upaya penanggulangan secara universal memuaskan, baik dari sudut prevensi, terapi, maupun rehabilitasi. Hawari, (1999:133).

Yang memprihatinkan adalah bahwa korban penyalahgunaan narkoba pada generasi muda, remaja bahkan orang dewasa sekalipun tidak takut akan bahya yang menimpa mereka, justru mereka yang sedangdalam usia produktif yang merupakan sumber daya manusia atau aset bangsa di kemudian hari. Akibatnya banyak yang cedera, cacat, hingga kematian akiabat penyalahgunaan narkoba adalah hal yang sia-sia, yang disebabkan karena overdosis, perkelahian, dan kecelakaan lalu lintas. Hawari, (1999:134).

Pengalaman di negara-negara yang maju, menunjukkan bahwa semakin modern dan industrial suatu masyarakat, maka penyalahgunaan narkoba semakin cenderung meningkat. Oleh karena itu bagi bangsa Indonesia, sudah harusnya mewaspadai akan bahayanya narkoba. Hawari, (1999:133-134).

2). Cara Pencegahan dan Penanggulangan Narkoba

Ada dua pendekatan dalam upaya pencegahan, yaitu upaya dalam jangka pendek, yang di harapkan efeknya akan segera Nampak, seperti larangan, hukuman, pertunjukan film akan akibat merusak dari penggunaan narkoba dan sebagainya. Dan upaya jangka panjang yaitu dengan menumbuhkan sikap dan kepribadian yang mendorong remaja ( kelompok manusia yang sangat rentan terhadap narkoba) untuk tidak melakukan tindakan tidak terpuji termasuk tidak terlibat dengan penggunaan narkoba ( dengan kata lain, mampu mengatakan " tidak" terhadap narkoba ) berdasarkan pertimbangan internal bukan karena ada pengawasan, larangan, hukuman dan sebagainya. Pendekatan ini harus dimulai sejak dini, dimulai dari pola asuh di rumah, iklim belajar di sekolah dan kondisi masyarakat. Utami munandar, (2009: 44 ). 
Hawari, (2003:4-5) bahwa upaya penanggulangan narkoba menurut dadang hawari, hingga sekarang belum ditemukan upaya penanggulangan penyalahgunaan zat secara universal, sempurna dan memuaskan baik dari aspek prevensi, terapi maupun rehabilitasi. Angka kekambuhan masih tinggi ( 43,9\% ), disebutkan pula penyalahgunaan ini merupakan penyakit kronis yang berulang kali kambuh ( a chronic relapsing disease ). Pada umumnya penyalahgunaan zat adalah laki-laki ( $94 \%$ ) dan dalam golongan usia antara 16-25 tahun sebanyak 71\%, penyalahgunaan zat tidak saja berbahaya dan merugikan diri pemakai, tetapi juga bagi keluarga dan menimbulkan dampak sosial yang cukup luas. Narkoba merupakan musuh nyata bagi segenap generasi bangsa ini, apabila salah menggunakannya akan mengakibatkan kecanduan dan menjurus kepada kematian. Indonesia begitu gencar dan serius dalam menangani penyalahgunaan narkoba, bahkan di kancah dunia Internasional, dengan bukti berlakunya UU No. 22 / 1997 tentang Narkoba tersebut memposisikan Indonesia di kancah dunia Internasional sebagai Negara yang mendukung gerakan perang terhadap Narkotika dan obat-obatan berbahaya serta tetap mengancam pidana pengguna narkotika untuk diri sendiri sebagai pelaku kejahatan yang harus dihukum ( pasal 85 ). Sekilas wajib bagi kita mengetahui sanksi hukum bagi pembuat dan pengedar narkoba begitu di perhatikan oleh pemerintah. Peredaran narkoba dalam hukum positif di Indonesia diatur di dalam Undang-undang No. 22 Tahun 1997 tentang narkotika. Menurut Undang-undang No. 22 Tahun 1997 tentang Narkotika, peredaran gelap narkotika adalah " setiap kegiatan atau serangkaian yang dilakukan secara tanpa hak dan melawan hukum yang ditetapkan sebagai tindak pidana narkotika “. ( UU RI, Narkotika :2011).

\section{Sanksi Bagi Pemakai dan Pengedar Narkoba Dalam Pandangan Hukum}

Adapun sanksi hukuman yang diberikan bagi para pengedar narkotika dengan pidana minimal penjara 2 tahun dan pidana maksimal hukuman mati atau seumur hidup yang diatur dalam BAB XII yaitu pasal 78, 79, 80, 82, 83, 84, 87 dan pasal 96, 97, 98, 99, dan pasal 100, Undangundang No. 22 Tahun 1997 tentang Narkotika.

Sekolah merupakan institusi dan lembaga pendidikan memiliki empat komponen penting. Pertama, sekolah menyediakan kerangka kerja bagi perencanaan, pengimplementasian dan pengevaluasian dalam upaya pencegahan dan pengurangan penyalahgunaan drug (termasuk alkohol dan rokok). Kedua, sekolah menyediakan lingkungan fisik dan sosial bagi 
pengembangan kesehatan siswa berkaitan dengan tujuan pendidikan yang ingin dicapai sesuai dengan jenjang pendidikan.

Peraturan pemerintah pendidikan dan kebudayaan (permendikbud) telah mengeluarkan berupa peraturan yang wajib untuk dipatuhi, ditaati oleh segenap insan pendidik. Terdapat pada permendikbud no.64 tahun 2015 berkaitan dengan dilarang keras. “ kawasan bebas asap rokok di lingkungan sekolah “. Permendikbud ini mengindikasikan bahwa merokok, atau asap rokok saja dilarang dilingkungan sekolah, apalagi yang berbentuk narkoba.

\section{Guru Pendidikan Agama Islam}

Guru Pendidikan Agama Islam secara singkat adalah pendidik yang mengajarkan tentang keislaman di dunia pendidikan formal.Pendidikan dapat diartikan sebagai bimbingan secara sadar oleh pendidik terhadap perkembanagan jasmani dan rohani peserta didik menuju terbentuknya kepribadian yang utama, sehingga pendidikan dipandang sebagai salah satu aspek yang memiliki peranan pokok dalam membentuk generasi muda agar memiliki kepribadian yang utama.

Dalam hal ini menurut Zuhairini, yang dikutip oleh Muhaimin menjelaskan bahwa dalam Islam pada mulanya pendidikan disebut dangan kata " $t a$ 'lim" dan " $t a{ }^{\prime} d i b$ " mengacu pada pengertian yang lebih tinggi, dan mencakup unsur-unsur pemgetahuan ('ilm), pengajaran ( $t a^{\prime} \mathrm{lim}$ ) dan pembimbingan yang baik (tarbiyah). Sedangkan menurut Langgulung (1997), pendidikan Islam itu setidak-tidaknya tercakup dalam delapan pengertian, yaitu Al-tarbiyah al-diniyah (pendidikan keagamaan), ta'lim al-din (pengajaran agama), al-ta'lim al-diny (pengajaran keagamaan), al-ta'lim al-Islamy (pengajaran keislaman), tarbiyah al-muslimin (pendidikan orang-orang Islam), al-tarbiyah fi al-Islam (pendidikan dalam Islam), altarbiyah 'inda al-muslimin (pendidikan di kalangan orang-orang Islam), dan al-tarbiyah al-Islamiyah (pendidikan Islam). Muhaimin, (2002: 36).

Para ahli pendidikan biasanya lebih menyoroti istilah tersebut dari aspek perbedaan anatara tarbiyah dan ta'lim, atau antara pendidikan dan pengajaran, sebagaimana sering diperbincangkan dalam karya-karya mereka.Di kalangan para penulis Indonesia, istilah pendidikan biasanya lebih diarahkan pada pembimbingan watak, moral sikap atau kepribadian, atau lebih mengarah pada afektif, sementara pengajaran lebih diarahkan pada penguasaan ilmu pengetahuan atau menonjolkan dimensi kognitif dan psikomotor. 
Akhir-akhir ini di kalangan masyarakat Indonesia istilah "pendidikan" mendapatkan arti yang sangat luas. Kata-kata pendidikan, pengajaran, bimbingan dan pelatihan, sebagai istilah-istilah teknis tidak lagi dibeda-bedakan oleh masyarakat kita, tetapi ketiga-tiganya lebur menjadi satu pengertian baru tentang pendidikan. (Muhaimin 2000: 37)

\section{Dasar Pendidikan Agama Islam}

Dasar pendidikan adalah suatu landasan yang dijadikan pegangan dalam menyelenggarakan pendidikan. Dasar pendidikan negara kita secara Yuridis Formal telah dirumuskan dalam:

1) Undang-Undang RI No. 2, 1989, tentang sistem pendidikan Nasional Bab II pasal 2 yaitu,"pendidikan Nasional berdasarkan pancasila dan UUD 1945.

2) Undang-Undang RI tentang Sistem Pendidikan Nasional (UUSPN) No. 20tahun 2003 memuat Tujuan Pendidikan Nasional sebagai berikut: "Pendidikan Nasional bertujuan berkembangnya potensi peserta didik agar menjadi manusia yang beriman dan bertakwa kepada Tuhan Yang Maha Esa, berpendidikan agama Islam mulia, sehat, berilmu, cakap, kreatif, mandiri, dan menjadi warga negara yang demokratis serta bertanggung jawab".

Dengan demikian jelaslah bahwa dasar pendidikan di Indonesia adalah Pancasila dan Undang-Undang Dasar 1945. Konsep dasar pendidikan agama Islam adalah konsep atau gambaran umum tentang pendidikan. Sumber pendidikan agama Islam adalah ajaran Islam, yaitu Al-Qur'an dan As-Sunnah. (Tajab 1996: 40).

\section{Tujuan Pendidikan Agama Islam}

Tujuan pendidikan agama Islam secara umum ialah,"meningkatkan keimanan, pemahaman, penghayatan, dan pengamalan peserta didik tentang agama Islam, sehingga menjadi manusia muslim yang beriman dan bertaqwa kepada Allah Swt serta berpendidikan agama Islam mulia dalam kehidupan kepribadian, bermasyarakat, berbangsa dan bernegara" (GBPP PAI, 2004).

\section{Kompetensi Kepribadian Guru Pendidikan Agama Islam}

Fachriddin dan Ali, ( 2009, 39-40 ) mengatakan bahwa setiap guru mempunyai pribadi masing-masing sesuai ciri-ciri- pribadi pribadi yang mereka miliki. Ciri-ciri inilah yang membedakan seorang guru dengan guru lainnya. Kepribadian sebenarnya adalah satu masalah abstrak, 
hanya dapat dilihat dari penampilan, tindakan, ucapan, cara berpakaian, dan dalam menghadapi setiap persoalan.

Sementara itu, yang dimaksud dengan kompetensi kepribadian di dalam Peraturan Pemerintah Nomor 19 Tahun 2005, pada pasal 28, ayat 3 ialah kemampuan kepribadian yang mantap, stabil, dewasa, arif, dan berwibawa, menjadi teladan bagi peserta didik, dan berakhlak mulia.

Kemudian menurut samani, mukhlas dalam fachruddin dan Ali, ( 2009 : 41 ) secara rinci kompetensi kepribadian mencakup hal-hal sebagai berikut : 1 ) berakhlakul mulia, 2) arif dan bijaksana, 3) mantap, 4 ) berwibawa, 5) stabil, 6) dewasa, 7) jujur, 8) menjadi teladan bagi peserta didik dan masyarakat, 9) secara objektif mengevaluasi kinerja sendiri, 10) mau siap mengembangkan diri secara mandiri dan berkelanjutan.

\section{Esksistensi Pendidikan Agama Islam di Sekolah}

Upaya meningkatkan mutu pendidikan sudah sejak lama dilakukan pemerintah. Beberapa aspek yang menjadi sasaran dalam upaya tersebut adalah meningkatkan kemampuan guru sehubungan dengan mutu Proses Belajar Mengajar (PBM). Meningkatkan kemampuan Kepala Sekolah sehubungan dengan pengelolaan dan manajemen sekolah. Kemampuan para supervisor/pengawas sehubungan dengan proses pengawasan dan penilaian pelaksanaan pendidikan di sekolah. Pembentukan komite sekolah/majelis madrasah sebagai upaya mengikut sertakan masyarakat dalam meningkatkan mutu pelayanan (dengan memberikan pertimbangan, arahan dan dukungan tenaga, sarana dan prasarana serta pengawasan pendidikan pada tingkat satuan pendidikan), dan akhirnya sampai pada inovasi kurikulum.

\section{METODOLOGI PENELITIAN}

Penelitian ini dilakukan sekolah PAB 4 Sampali Deli Serdang. Metode yang digunakan dalam penelitian ini adalah kualitatif. Instrumen pengumpulan data yang digunakan adalah observasi, wawancara dan dokumentasi. Analisis data yang dilakukan menggunakan Miles dan Huberman.

\section{TEMUAN DAN PEMBAHASAN PENELITIAN}

Dampak positif dari upaya kepala sekolah dan guru pendidikan agama Islam dalam mencegah penyalahgunaan narkoba di SMA PAB 4 Sampali Deli Serdang, diantaranya adalah sebagai berikut: (1) memberikan ketenangan, kenyamanan, dan kedamaian dalam 
melaksanakan aktivitas bagi segenap unsur pendidik, peserta didik, dan perangkat sekolah lainnya, (2) membangkitkan semangat bagi segenap unsur pendidik dan peserta didik untuk mencapai atau meraih prestasi di berbagai bidang, (3) bagi orang tua siswa, semakin percaya menyekolahkan putra/I nya di SMA PAB 4 Sampali Deli Serdang, karena suasana sekolah yang semakin meningkatkan kualitas keilmuannya maupun skill dalam menghadapi tantangan zaman, dan terbebas dari pengaruh negatif termasuk penyalahgunaan narkoba, dan (4) SMA PAB 4 Sampali selama ini, dengan istilah yang biasa di ucapkan kepala sekolah bahwa " SMA PAB 4 Sampali ini Miskin Prestasi " untuk itu, tugas utama saya dan guru-guru lainnya adalah membangkitkan semangat siswa/I dalam berkompetisi dalam bidang olahraga dan lain-lain, sehingga membuat SMA PAB 4 Sampali meraih kesuksesan dan kaya akan prestasi.

Hasil wawancara dengan salah seorang guru di SMA tersebut beliau menuturkan bahwa dampak positif yang kami dan saya rasakan selaku pendidik di sekolah ini adalah " Dalam dua tahun terakhir ini, kami merasakan jumlah penyalahgunaan narkoba sangat sedikit sekali dibandingkan dari tahun-tahun sebelumnya, dan saya berkeyakinan bahwa tahun depan penyalahgunaan narkoba di sekolah ini akan hilang. kami merasakan salut terhadap upaya tegas dari kepala sekolah dan guru agama Islam serta seluruh guru pada umumnya yang telah bekerja sama untuk melakukan pengembalikan kepercayaan masyarakat untuk menyekolahkan anaknya di sekolah SMA PAB 4 Sampali.

Dengan demikian, upaya-upaya ini sangat baik untuk di terapkan di berbagai sekolah seluruh Indonesia. Supaya penyalahgunaan narkoba dapat dihindarkan di jauhi dalam kehidupan berbangsa dan bernegara.

\section{SIMPULAN}

Demikianlah upaya kepala dan guru pendidikan agama Islam dalam mencengah penyalahgunaan narkoba, dengan upaya-upaya diatas mudah-mudahan segala bentuk penyalahgunaan narkoba dengan jenis apapun di sekolah SMA PAB 4 Sampali Deli Serdang ini, dapat diterapkan di sekolah manapun. Sehingga dapat terbebas dari penyalahgunaan narkoba.

\section{DAFTAR PUSTAKA}

Abbas, (1991) Pilihan Hadits Politik, Ekonomi, dan Sosial. Jakarta: Pustaka Panjimas 
Abin, Makmun, Syamsuddin, (2005) Psikologi Kependidikan Bandung: Remaja Rosdakarya.

Ali, Muhammad, (2000) Guru Dalam Proses Belajar Mengajar Bandung: Sinar Baru.

Abu Bakar, (2009) kinerja kepala sekolah dalam kegiatan bimbingan konseling. Bandung: Citapustaka Media Perintis.

Anwar, husnel, (2017) Islam Kaffah. Medan: Perdana publishing.

Darajad, Zakiah . (1979) Ilmu Jiwa Agama. Jakarta: Bulan Bintang.

Daryanto H.M, (2001) Administrasi Pendidikan. Jakarta: Rineka Cipta.

Dirawat dkk. (1983) Pengantar Kepemimpinan Pendidikan. Surabaya: Usaha Nasional.

Donni, (2017) Menjadi Kepala Sekolah Dan Guru Profesional, Bandung : pustaka setia.

Fatimah, (2006) Psikologi Perkembangan ( Perkembangan Peserta didik), Bandung :Pustaka Setia.

Hawari, dadang, (1999) Alquran ilmu kedokteran dan kesehatan jiwa. Yogyakarta: Dana Bhakti Prima Yasa.

Kartono, (2008) Patologi Sosial 2: Kenakalan Remaja. Jakarta: RajaGrafindo Persada.

Kementerian Agama RI, (2002) Alquran dan Terjemahnya Semarang: Toha Putra.

Kusrini, (1991) Strategi Pembelajaran Pendidikan Agama Islam, Malang: IKIP Malang.

Mulkan, (2002) Nalar Spiritual Pendidikan, Yogyakarta: Tiara Wacana.

Moleong, (2007) Metodologi Penelitian Kualitatif. Bandung: Remaja Rosda karya.

Muhaimin, (2003) Wacana Pengembangan Pendidikan Islam, Jakarta: Pustaka Pelajar 